\title{
EVALUATION OF ECOLOGICAL EFFICIENCY RESULTING FROM THE APPLICATION OF MODERN BUSES IN URBAN COMMUNICATIONS
}

\author{
Halina Marczak ${ }^{1}$ \\ 1 Institute of Transport, Internal Combustion Engines and Ecology, Lublin University of Technology, \\ Nadbystrzycka 36, 20-618 Lublin, Poland, e-mail: h.marczak@pollub.pl
}

Received: 2017.06.09

Accepted: 2017.08.01

Published: 2017.09.01

\begin{abstract}
The use of modern vehicles may contribute to limiting the adverse impact of urban transport on the environment. Evaluation of the options for choosing new means of transport in terms of economic and ecological benefits allows for the identification of the most advantageous variants. The solution is to consider replacing a bus compliant with a Euro III norm (base variant) with a one compliant with Euro VI (option 1) or with an electric counterpart (option 2). The evaluation of the solutions was based on the calculated parameters: a monetary value reflecting the energy cost of the analyzed buses and the ecological effect of the reduced emissions from the Euro VI bus or the electric bus compared with the Euro III vehicle. The ecological effect resulting from the use of the electric bus was determined taking into account the emissions from fossil fuels (coal, natural gas) and biomass. The method of cost analysis was used to evaluate the solution of replacing older buses with new ones (with different types of propulsion). It is based on calculating the unit cost of achieving the ecological effect of the solution.
\end{abstract}

Keywords: ecological effect, public transport, low-emission diesel bus, electric bus, cost of energy consumption

\section{INTRODUCTION}

Nowadays, companies pay a lot of attention to improving their environmental performance, expressing their responsibility for the environment. By taking the environmental actions they see the opportunity to obtain economic benefits, which are reflected in the reduction of operating costs of the company. Indeed, meeting the environmental objectives within an enterprise can lead to energy savings, rational use of natural resources, reduced emissions of by-products to the environment and reduced environmental risks. It is important that companies' environmental activities should be continuous and ensure compliance with environmental requirements.

The environmental policy of companies depends on the specific nature of their activity and related environmental aspects. The assessment pertaining to the importance of environmental aspects can be used to identify the sources of the greatest threats and identify the ways of minimizing the harmful effects on the environment.

The analysis of the environmental aspects of public transport companies shows that significant aspects include, inter alia, emission of pollutants from vehicles driven by an internal combustion engine, emission of noise, consumption of energy resources and other environmental resources and generation of waste. Recognition of pollutant emissions into the air as a significant environmental aspect is the basis for the action aiming at their reduction. The considered solution may be replacing the old fleet with new buses, meeting the highest European emission standards, or buses with an unconventional drive, e.g. electric. Another way is to use high-quality fuels to drive high-quality combustion vehicles or take actions to reduce the fuel consumption (e.g. by using tires with lower rolling resistance and higher durability).

Prior to exchanging the fleet of buses, an analysis of economic and environmental aspects 
of various options should be conducted. Assessing the effects of planned and implemented environmental tasks is also one of the components of systemic environmental management. The main indicators used in this assessment are energy efficiency, efficient use of materials and water, air emissions and waste generation (detailing the amount of waste recovered, recycled, used in energy production, storage). On the basis of the environmental performance indicators, the progress in eliminating negative environmental impacts of urban transport activities can be assessed.

The article presents a comparative analysis of the energy costs of public buses with diesel and electric drives. In addition, the environmental impact of low-emission diesel buses and electric buses has been assessed.

\section{METHOD AND ASSUMPTIONS}

The author used a method involving the analysis of technical parameters, investment expenditures and operating costs of urban buses, as well as the data on the pollutant emissions from electric power generation processes for electric vehicles and European emission limit values for heavy vehicles. The data sources come from bus manufacturers, power companies and literature. The collected data were used to determine the vehicle's energy consumption during the assumed time of use and to calculate the environmental effect of the use of modern city buses.

The emission quotient of the reference variant (base) and pollutant emissions in the alternative variant was assumed as a measure of ecological effect. The base variant is a diesel bus with Euro III emissions. The subject of evaluation in the alternative variant includes: a bus with an internal combustion engine compliant with the Euro VI emission standard and an electric bus. The author analysed the buses made by Solaris Bus \& Coach S.A. Based on [Regulation...2011], buses' life cycle was assumed at $800,000 \mathrm{~km}$. With a daily limit of mileage around $220 \mathrm{~km}$, it takes 10 years for a bus to reach such a mileage. A financial analysis was conducted for constant prices (excluding inflation) and net value without VAT.

\section{Determining the cost of energy consumption during the life cycle of public transport vehicles}

For electric vehicles, the energy consumption is equal to the amount of electricity used. For the vehicles powered by an internal combustion engine, the annual energy consumption can be determined by the formula [Marczak 2016]:

$$
Z E_{t}=Z P_{t} \cdot W_{e} \cdot P_{t}
$$

where: $Z E_{t}$ - energy consumption, $\mathrm{MJ} / \mathrm{km}$

$Z P_{t}-$ fuel consumption, $\mathrm{dm}^{3} / \mathrm{km}$

$W_{e}$ - energy value of fuel, $\mathrm{MJ} / \mathrm{dm}^{3}$

$P_{t}{ }^{e}$-vehicle mileage.

The monetary value reflecting the energy consumption over the life cycle of a vehicle can be calculated by the following formula:

$$
K_{E}=\sum_{t=0}^{t=n} Z E_{t} \cdot k_{j}
$$

where: $K_{E}$ - energy costs in a 10 -year time horizon, PLN

$k_{i}$ - monetary value per unit of energy, $\mathrm{PLN} / \mathrm{MJ}$

$t$ - year; $t$ assumes the values from 0 to $n$ ( 0 denotes the year in which the first costs are incurred, $n$ - the last year included in the analysis).

The monetary value per unit of energy $k_{j}$ is the lower of the cost related to $1 \mathrm{MJ}$ of energy from motor gasoline or pre-tax diesel [Regulation...2011]. The parameter $k_{j}$ was calculated from the dependence:

$$
k_{j}=\min \left(\frac{c_{G}}{W_{e_{-} G}} ; \frac{c_{D}}{W_{e_{-} D}}\right)
$$

where: $c_{G}$ - the price of gasoline before taxation, PLN $/ \mathrm{dm}^{3}$

$C_{D}$ - the price of diesel fuel before taxation, $\mathrm{PLN} / \mathrm{dm}^{3}$

$W_{e_{-} G}$ - energy value of gasoline, $\mathrm{MJ} / \mathrm{dm}^{3}$

$W_{e_{-}-}^{e_{-} G}-$ energy value of diesel fuel, $\mathrm{MJ} / \mathrm{dm}^{3}$

The average retail price of diesel in Poland before tax (excluding margin and VAT) is 3.39 $\mathrm{PLN} / \mathrm{dm}^{3}$ and the cost of gasoline (Pb95) amounts to $3.53 \mathrm{PLN} / \mathrm{dm}^{3}$ (as of 04.05 .2017 according to www.reflex.com.pl). Taking these prices and energy value of diesel fuel $\left(36 \mathrm{MJ} / \mathrm{dm}^{3}\right)$ and gasoline $32 \mathrm{MJ} / \mathrm{dm}^{3}$ into account [Regulation...2011] it was specified that:

$$
\begin{aligned}
k_{j} & =\min \left(\frac{3.53 P L N / d^{3}}{32 \mathrm{MJ} / \mathrm{dm}^{3}} ; \frac{3.39 P L N / \mathrm{dm}^{3}}{36 \mathrm{MJ} / \mathrm{dm}^{3}}\right) ; \\
k_{j} & =0.094 P L N / \mathrm{MJ}
\end{aligned}
$$


According to the recommendations [Blue Book 2015], the changes in energy costs over time have not been taken into account. Adoption of this assumption is justified by the fact that any increase in energy costs will be balanced by the increased energy efficiency of vehicles.

The described method of determining the cost of energy consumption is illustrated by the example of urban buses that differ in their source of propulsion, i.e. a diesel engine that complies with the Euro VI emission standard and with an electric motor. The technical characteristics of the vehicles are given in Tables 1 and 2.

The results of the calculations of the energy cost for the mileage of vehicles of $800,000 \mathrm{~km}$ (10 years) are presented in Table 3 and Figure 1. The presented results show that the cost of energy consumption during the 10 years of use of the diesel bus is $62.5 \%$ greater than for electric bus.

Replacing a Euro III internal combustion engine bus with a new Euro VI vehicle generates benefits of a lower emission charge for air pollution. The annual fee for the use of the environment in a form of emissions of gases and particulates produced by the internal combustion engines of the analyzed buses and emitted into the air was calculated from the following dependence:

$$
O_{t}=P_{t} \cdot Z P_{t} \cdot \rho \cdot s
$$

where: $O_{t}-$ yearly fee, PLN

$$
\begin{aligned}
& P_{t}, Z P_{t}-\text { as in }(1) \\
& \rho-\text { density of diesel fuel, assumed at } \\
& \rho=0.845 \mathrm{~kg} / \mathrm{dm}^{3} \\
& S-\text { unit price }[\text { Notice...2016]. }
\end{aligned}
$$

The fee depends on Euro standard (Fig. 2).

\section{Method of determining the ecological effect resulting from the application of new city buses}

The key air pollutants from road transport are nitrogen oxides $\left(\mathrm{NO}_{\mathrm{x}}\right)$, carbon monoxide $(\mathrm{CO})$, hydrocarbons (HC), and suspended solids (PM). They have a negative impact on the health of people with cardiovascular and respiratory diseases. In addition, they adversely affect the material goods (damage to buildings, engineering ob-

\begin{tabular}{|c|c|c|}
\hline Model & \multicolumn{2}{|l|}{ Urbino 12} \\
\hline Producer & \multicolumn{2}{|c|}{ Solaris Bus \& Coach S.A. } \\
\hline Length [m] & \multicolumn{2}{|l|}{12} \\
\hline \multirow[b]{2}{*}{ Engine } & Standard & Cumminis ISB6.7E6 280B (209 kW) \\
\hline & Option & $\begin{array}{l}\text { Cummins ISB6.7E6 250B (187 kW) } \\
\text { DAF MX11 } 210(210 \mathrm{~kW}) \\
\text { DAF MX11 } 240(240 \mathrm{~kW}) \\
\text { DAF MX11 } 271(271 \mathrm{~kW})\end{array}$ \\
\hline Engine capacity $\left[\mathrm{dm}^{3}\right]$ & \multicolumn{2}{|c|}{6.692 (standard engine) } \\
\hline \multirow{2}{*}{ Gear box } & Standard & Voith Diwa 6 \\
\hline & Option & ZF Ecolife \\
\hline $\begin{array}{l}\text { Fuel consumption } \\
{\left[\mathrm{dm}^{3} / 100 \mathrm{~km}\right]}\end{array}$ & \multicolumn{2}{|l|}{$40\left(^{*}\right)$} \\
\hline Emission norm & \multicolumn{2}{|l|}{ Euro VI } \\
\hline
\end{tabular}
jects) and other components of the environment (limitation of the diversity of living organisms, reduction of soil productivity). The ecological ef-

Table 1. Technical parameters of a bus with a diesel engine [Catalogue...2016]

$(*)$ - monthly average with heating or air conditioning on [MPK...2017]

Table 2. Technical parameters of an electric bus [Catalogue...2016]

\begin{tabular}{|l|l|l|}
\hline \multicolumn{2}{|l|}{ Model } & Urbino 12 electric \\
\hline Produceer & Solaris Bus \& Coach S.A. \\
\hline \multirow{2}{*}{ Length [m] } & 12 \\
\hline \multirow{2}{*}{ Bngine } & Standard & Asynchronic $160 \mathrm{~kW}$ \\
\cline { 2 - 3 } & Option & Engines in axles ZF AVE130 2x60 kW \\
\hline \multirow{2}{*}{ Charging system } & Standard & $\begin{array}{l}\text { Lit-ion batteries operatable (capable of using without break) up to 24 h/day } \\
\text { (depending on capacity and charging method) }\end{array}$ \\
\hline \multicolumn{2}{|l|}{ Energy consumption $[\mathrm{MWh} / \mathrm{km}]$} & Plug-in \\
\cline { 2 - 3 } & Standard & Pantograph \\
\hline
\end{tabular}


Table 3. Costs of energy consumption in modern urban buses in the period of 10 years

\begin{tabular}{|l|c|c|c|c|}
\hline Model & $\begin{array}{c}\text { Diesel consumption } \\
{\left[\mathrm{dm}^{3} / \mathrm{km}\right]}\end{array}$ & $\begin{array}{c}\text { Electric energy } \\
\text { consumption } \\
{[\mathrm{MWh} / \mathrm{km}]}\end{array}$ & $\begin{array}{c}\text { Energy consumption } \\
{[\mathrm{MJ} / \mathrm{km}]}\end{array}$ & $\begin{array}{c}\text { Cost of energy in 10-year } \\
\text { life cycle } \\
{[\text { PLN] }}\end{array}$ \\
\hline Solaris Urbino 12 (Euro VI) & 40 & - & 14.4 & $1,082,880$ \\
\hline Solaris Urbino 12 Electric & - & 0.0015 & 5.4 & 406,080 \\
\hline Solaris Urbino 12 (Euro III) & 43.7 & - & 15.73 & $1,183,046$ \\
\hline
\end{tabular}

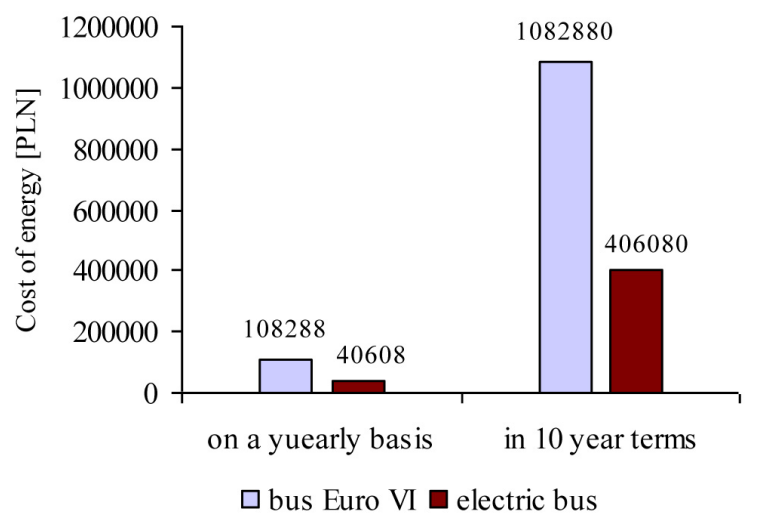

Figure 1. Cost of energy in urban buses per year and in the whole lifecycle

fect resulting from the emission reduction of each substance into the air was calculated according to the following formula:

$$
E E_{i}=\frac{E_{i b}}{E_{i}}
$$

where: $E E_{i}$ - ecological effect resulting from limiting pollution

$E_{i b}$ - the size of reference pollution, $\mathrm{g} / \mathrm{km}$ $E_{i}-$ the size of analysed pollution, $\mathrm{g} / \mathrm{km}$.

The value of $E E_{i}$ parameter above 1 indicates that pollution emission was reduced. The annual emission of pollutants was determined according to the following formula:

$$
E_{i}=P \cdot e_{i}
$$

where: $P$ - yearly mileage, $\mathrm{km}$

$e_{i}-$ unit emission (emission index) of polutants $\mathrm{g} / \mathrm{km}$.

The pollutant emission rates are calculated using the Copert IV software (version 10.0), developed under the auspices of the European Environment Agency (EEA) in cooperation with the Joint Research Center (JRC). The calculation algorithm takes into account many factors affecting the emission of pollutants from the means of road transport including, among others, the average speed of the vehicle, type of road infrastructure (city, out-of-town, motorway), type (e.g. passen-

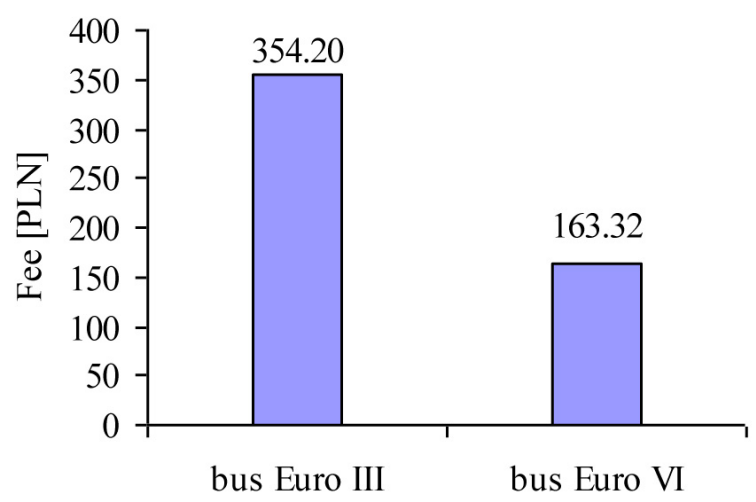

Figure 2. Yearly fee on diesel fuel for gases and pollutants from bus engines depending on Euro standard

ger, other than passenger, heavy duty) and parameters characterizing the vehicle (e.g. fuel type, engine capacity, permissible vehicle mass, Euro emission standard). Table 4 lists the $\mathrm{CO}, \mathrm{NO}_{\mathrm{x}}$, $\mathrm{HC}, \mathrm{PM}$ emissions and fuel consumption for diesel engine, estimated with Copert IV (version 10.0). These values are appropriate for $50 \%$ bus load and zero slope of the road [Report...2015]. In Table 4, in addition to Copert IV emissions indicators in $\mathrm{g} / \mathrm{km}$, the values of these indicators were also converted to $\mathrm{g} / \mathrm{kWh}$. The calculations were made assuming that the unit consumption of diesel fuel is $225 \mathrm{~g} / \mathrm{kWh}$. The fuel consumption in $\mathrm{dm}^{3} / 100 \mathrm{~km}$ was calculated taking into account that diesel fuel density is $0.845 \mathrm{~kg} / \mathrm{dm}^{3}$. The $\mathrm{CO}_{2}$ emission was calculated using the unit $\mathrm{CO}_{2}$ emission factor: $2.52 \mathrm{~kg} / \mathrm{dm}^{3}$.

In comparison with the Euro emission standards shown in Table 4, Table 5 lists the requirements of Euro III-VI for passenger vehicles (category M, excluding M1) and for the vehicles (category $\mathrm{N}$ ) equipped with a diesel engine or a spark-ignition engine. These limit values apply to the test conditions in the European Transition Cycle (ETC) or WHTC (World Harmonized Transient Cycle) test.

The calculations of annual emission of pollutions for the reference value and for a low emission combustion engine are presented in Table 6 . The calculations consider emission indicators for 
Table 4. Unit emission of pollutants from a diesel city bus according to Copert IV software [own study based on Report...2015]

\begin{tabular}{|c|c|c|c|c|c|c|c|c|}
\hline \multicolumn{9}{|c|}{ City bus (length $12 \mathrm{~m}$ ) } \\
\hline \multicolumn{7}{|c|}{ Indicators according to Copert IV } & \multicolumn{2}{|c|}{ Calculated values } \\
\hline $\begin{array}{c}\text { Average } \\
\text { speed } \\
{[\mathrm{km} / \mathrm{h}]}\end{array}$ & $\begin{array}{l}\text { Norm of } \\
\text { emissions }\end{array}$ & $\mathrm{CO}$ & $\mathrm{NO}_{x}$ & $\mathrm{HC}$ & PM & $\begin{array}{l}\text { Fuel consumption } \\
{[\mathrm{g} / \mathrm{km}]}\end{array}$ & $\begin{array}{l}\text { Fuel consumption } \\
{\left[\mathrm{dm}^{3} / 100 \mathrm{~km}\right]}\end{array}$ & $\mathrm{CO}_{2}[\mathrm{~g} / \mathrm{km}]$ \\
\hline \multirow{4}{*}{20} & \multirow{4}{*}{ Euro III } & & & & & \multirow{4}{*}{361} & \multirow{4}{*}{42.7} & \multirow{4}{*}{$1,076.6$} \\
\hline & & 3.02 & 11.28 & 0.61 & 0.23 & & & \\
\hline & & \multicolumn{4}{|c|}{ Calculated into $\mathrm{g} / \mathrm{kWh}$} & & & \\
\hline & & 1.88 & 7.03 & 0.38 & 0.14 & & & \\
\hline \multirow{4}{*}{20} & \multirow{4}{*}{ Euro VI } & & & & & \multirow{4}{*}{333} & \multirow{4}{*}{39.4} & \multirow{4}{*}{993.1} \\
\hline & & 1.49 & 0.8 & 0.04 & 0.01 & & & \\
\hline & & \multicolumn{4}{|c|}{ Calculated into g/kWh } & & & \\
\hline & & 1.00 & 0.54 & 0.03 & 0.007 & & & \\
\hline \multirow{4}{*}{30} & \multirow{4}{*}{ Euro III } & & & & & \multirow{4}{*}{293} & \multirow{4}{*}{34.7} & \multirow{4}{*}{873.8} \\
\hline & & 2.07 & 8.43 & 0.42 & 0.17 & & & \\
\hline & & \multicolumn{4}{|c|}{ Calculated into $\mathrm{g} / \mathrm{kWh}$} & & & \\
\hline & & 1.59 & 6.47 & 0.32 & 0.13 & & & \\
\hline \multirow{4}{*}{30} & \multirow{4}{*}{ Euro VI } & & & & & \multirow{4}{*}{277} & \multirow{4}{*}{32.8} & \multirow{4}{*}{826.1} \\
\hline & & 1.09 & 0.45 & 0.03 & 0.00 & & & \\
\hline & & \multicolumn{4}{|c|}{ Calculated into $\mathrm{g} / \mathrm{kWh}$} & & & \\
\hline & & 0.88 & 0.37 & 0.02 & 0.00 & & & \\
\hline
\end{tabular}

Table 5. Boundary values of pollutant emissions for Euro norms [Directive 2005, Comission Resolution (EU) 2014]

\begin{tabular}{|c|c|c|c|c|c|c|}
\hline \multirow[t]{2}{*}{ Norm } & \multirow[t]{2}{*}{ Test } & $\mathrm{CO}$ & $\mathrm{NO}_{x}$ & $\begin{array}{c}\mathrm{HC} \\
\text { (non-methane) }\end{array}$ & $\left.\mathrm{CH}_{4}{ }^{*}\right)$ & PM \\
\hline & & \multicolumn{5}{|c|}{$\mathrm{g} / \mathrm{kWh}$} \\
\hline Euro III & \multirow{3}{*}{ ETC } & 5.45 & 5.0 & 0.78 & 1.6 & 0.16 \\
\hline Euro IV & & 4.0 & 3.5 & 0.55 & 1.1 & 0.03 \\
\hline Euro $\mathrm{V}$ & & 4.0 & 2.0 & 0.55 & 1.1 & 0.03 \\
\hline Euro VI & WHTC & 4.0 & 0.46 & $0.16(")$ & 0.5 & 0.01 \\
\hline
\end{tabular}

(*) for gas engines (Euro III-V: natural gas, Euro VI: natural gas and LPG); (**) total hydrocarbons for diesel engines

Table 6. Annual emission in a reference variant (bus with Euro III standard) and alternative variant (bus with Euro VI variant)

\begin{tabular}{|c|c|c|}
\hline \multirow{2}{*}{ Substance } & \multicolumn{2}{|c|}{ Calculated annual emission } \\
\cline { 2 - 3 } & Reference variant [g/year] & Bus with Euro VI engine [g/year] \\
\hline $\mathrm{CO}$ & 241,600 & 119,200 \\
\hline $\mathrm{NO}_{\mathrm{x}}$ & 902,400 & 64,000 \\
\hline $\mathrm{HC}$ & 48,800 & 3,200 \\
\hline $\mathrm{PM}$ & 18,400 & 800 \\
\hline $\mathrm{CO}_{2}$ & $86,128,000$ & $79,448,000$ \\
\hline
\end{tabular}

the average speed of $20 \mathrm{~km} / \mathrm{h}$ (Tab. 4). Figure 3 illustrates the calculated values of ecological effect in a form of emission reduction by using a bus compliant with Euro VI standard, in comparison to Euro III bus.
The value of ecological effect greater than 1 (Fig. 3) indicates the emission of each pollutant was reduced in relation to the reference variant. The highest value of the effect (23) was obtained for solids and the lowest for carbon dioxide (1.08). 


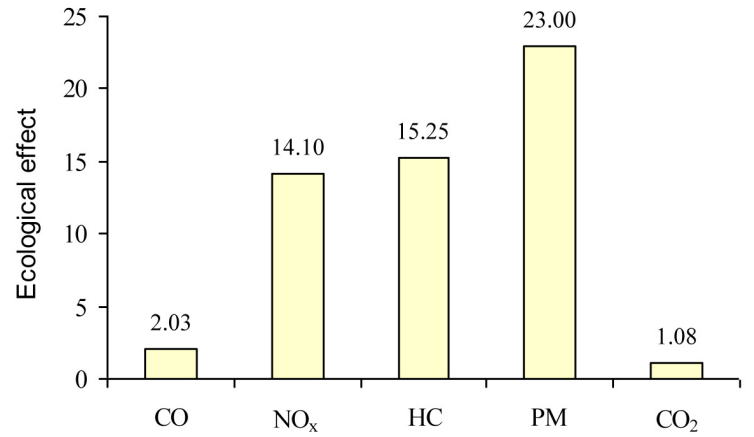

Figure 3. Ecological effect of using a bus compliant with Euro VI standard, in comparison to Euro III bus

The emission of pollutants from electric buses into the air at their places of use is zero; however, it occurs in the processes of electricity production. In the latter case, the amount of pollutant emissions depends on the type of primary energy carrier. The considerations take into account the emission factors from the production of electricity from fossil fuels (coal, natural gas) and biomass, given in Table 7. The annual emission of pollutants from electricity production process used to drive an electric bus was calculated on the basis of these indicators. The results of these calculations and the annual ecological effect of using the electric bus as compared to the reference variant are summarized in Table 7.

The obtained results of the calculations (Table 7) show that the environmental effect resulting from $\mathrm{PM}$ and $\mathrm{NO}_{\mathrm{x}}$ reduction is the greatest for the variant with electric bus powered by a gasfired power plant. The highest $\mathrm{CO}$ reduction $\left(E E_{i}\right.$ $=503.33$ ) was achieved in the case of electricity production from biomass. In the balance of $\mathrm{CO}_{2}$ emissions, biomass is treated as a fuel that does not emit $\mathrm{CO}_{2}$. As a consequence, biomass has achieved a very high value of the ecological effect resulting from the reduction of $\mathrm{CO}_{2}$ emissions. On the other hand, in the aspect of $\mathrm{CO}_{2}$ reduction, a variant of the electric bus from a coal-fired power plant is disadvantageous. The annual $\mathrm{CO}_{2}$ emissions in the above variant are $28 \%$ higher than in the base variant.

The method of cost analysis was used to evaluate, from an economic and environmental perspective, the solution of replacing older buses with new ones (with different types of propulsion). It is based on calculating the unit cost of achieving the ecological effect. This indicator was calculated from the following formula:

$$
K_{j}=\frac{\sum_{t=0}^{t=n}\left(N I_{t}+K E_{t}\right)}{\sum_{t=0}^{t=n} E E_{i}}
$$

where: $K_{j}$ - unit cost of achieving ecological effect from the activity, PLN

$\mathrm{NI}_{\mathrm{t}}$ - investment costs, PLN

$K E_{t}$ - exploitation costs, PLN

$E E_{i}-$ ecological effect

$t-$ as in Eq. (2).

Table 7. Emission of pollutants for a power plant and ecological effect of using an electric bus [PGE GiEK data 2016]

\begin{tabular}{|c|c|c|c|c|}
\hline \multirow[b]{2}{*}{ Substance } & \multicolumn{2}{|c|}{ Emission factors } & \multirow{2}{*}{$\begin{array}{l}\text { Annual emission of production } \\
\text { of electricity consumed by } \\
\text { electric bus [g/year] }\end{array}$} & \multirow{2}{*}{$\begin{array}{c}\text { Annual ecological } \\
\text { effect }\end{array}$} \\
\hline & $\begin{array}{c}\text { g/MWh of produced } \\
\text { energy }\end{array}$ & $\mathrm{g} / \mathrm{km}$ of distance & & \\
\hline \multicolumn{5}{|c|}{ Coal power plant } \\
\hline $\mathrm{CO}$ & $188\left(^{*}\right)$ & 0.282 & 22,560 & 10.71 \\
\hline $\mathrm{NO}_{x}$ & 900 & 1.35 & 108,000 & 8.36 \\
\hline PM & 30 & 0.045 & 3,600 & 5.11 \\
\hline $\mathrm{CO}_{2}$ & 920,600 & $1,380.9$ & $110,472,000$ & 0.78 \\
\hline \multicolumn{5}{|c|}{ Natural gas power plant } \\
\hline $\mathrm{CO}$ & $99\left({ }^{*}\right)$ & 0.149 & 11,920 & 20.27 \\
\hline $\mathrm{NO}_{\mathrm{x}}$ & 100 & 0.15 & 12,000 & 75.2 \\
\hline PM & 2 & 0.003 & 240 & 76.67 \\
\hline $\mathrm{CO}_{2}$ & 261,000 & 391.5 & $31,320,000$ & 2.75 \\
\hline \multicolumn{5}{|c|}{ Biomass power plant } \\
\hline $\mathrm{CO}$ & 4 & 0.006 & 480 & 503.33 \\
\hline $\mathrm{NO}_{\mathrm{x}}$ & 920 & 1.38 & 110,400 & 8.17 \\
\hline PM & 50 & 0.075 & 6,000 & 3.07 \\
\hline $\mathrm{CO}_{2}$ & - & - & $0.1\left(^{* *}\right)$ & $861,280,000$ \\
\hline
\end{tabular}

(*) after [Kubik B. 2014]; (**) the value assumed for calculations 


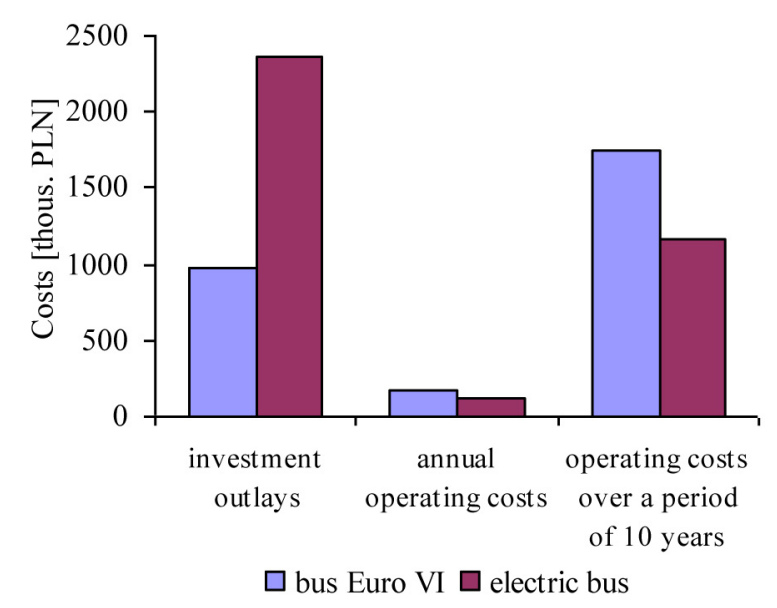

Figure 4. Costs of purchase and exploitation of modern city buses

The net investment for the purchase of Solaris Urbino 12 diesel bus with a Euro VI standard diesel engine is 971,615 PLN [MPK...2017]. The cost of operating the bus consists of the cost of energy consumption in the amount of 108,288 PLN/year (Table 3) and costs other than fuel consumption, which amount to an average of 330,193 PLN over the period of 5 years $(66,039$ PLN/year/ piece) [Kubik 2014].

The investment expenditures in the case of an electric bus include the purchase of vehicle and the charging infrastructure. As regards the cost of purchasing two types of chargers: plug-in type $(32 \mathrm{~kW})$ for charging in a depot of 51,500 PLN [MPK...2017] and high power $(220 \mathrm{~kW})$ for charging outside the depot of 300,000 PLN [Kubik 2014]. The purchase price of the Solaris Urbino 12 electric bus is 2,008,794 PLN [MPK...2017]. The operating costs, however, include: energy costs of 40,608 PLN/year (Table 3), costs other than energy consumption of 69,020 PLN/year as well as 1,500 PLN/pcs. and 5,000 PLN/pcs., respectively, corresponding to the chargers for loading inside and outside the depots .
The costs of buying and operating a low-carbon diesel bus and an electric bus are shown in Figure 4. Table 8 shows the unit cost of achieving an environmental effect, calculated separately for each pollutant and variant over a 10 -year period. The results obtained are the basis for assessing the scale of achieved results in relation to the assumed costs of planned solutions. The lowest $K_{j}$ value has been obtained for the local use of an electric bus, i.e. at its place of use, where there is no emission of pollutants. The best cost-effectiveness was also obtained for the electric bus including the emissions from the production of electricity from gaseous fuel. For this source of energy, the unit cost $K_{j}$ is lower for all the pollutants analyzed and for the electric bus than for the internal combustion engine. A standard engine bus is characterized by a better $K_{j}$ value for $\mathrm{NO}_{x}, \mathrm{PM}$ and $\mathrm{CO}_{2}$, as compared to the electric bus powered from a coal-fired power plant and when emissions are taken into account in the power generation process.

\section{CONCLUSION}

One of the methods to reduce the harmful impact of urban transport on the environment is to use modern buses. Evaluation of the variants pertaining to the use of new means of transport in the economic aspect and the ecological benefits allows to indicate the most advantageous solutions. The subject of the discussion was the analysis of the solution involving replacing a bus compliant with Euro III standard (base variant) bus with a Euro VI compliant bus (option 1) or with an electric bus (option 2).

The comparison of the energy cost characterizing a bus with Euro VI over a 10-year period of use shows that it is $62.5 \%$ more expensive than the electric bus.

Table 8. Unit costs of ecological effect for the analysed variants

\begin{tabular}{|c|c|c|c|c|c|}
\hline \multirow{2}{*}{\multicolumn{2}{|c|}{ Item }} & \multicolumn{4}{|c|}{ Unit costs of ecological effect $K_{j}[\mathrm{PLN}]$} \\
\hline & & $\mathrm{K}_{i}-\mathrm{CO}$ & $K_{j}-\mathrm{NO}_{\mathrm{x}}$ & $K_{j}-\mathrm{PM}$ & $\mathrm{K}_{i}-\mathrm{CO}_{2}$ \\
\hline \multicolumn{2}{|c|}{ Standard Euro VI bus } & $133,936.1$ & $19,254.5$ & $11,803.85$ & $250,450.6$ \\
\hline \multirow{4}{*}{ 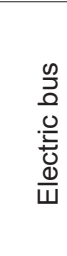 } & In the place of use & 0.1458 & 0.0390 & 1.9139 & 0.0004 \\
\hline & $\begin{array}{l}\text { Including emission from a coal-powered } \\
\text { power plant }\end{array}$ & $32,881.18$ & $42,124.09$ & $68,915.34$ & $451,483.8$ \\
\hline & $\begin{array}{l}\text { Including emission from a natural gas- } \\
\text { powered power plant }\end{array}$ & $17,373.33$ & $4,682.94$ & $4,593.16$ & $128,057.2$ \\
\hline & $\begin{array}{l}\text { Including emission from a biomass power } \\
\text { plant }\end{array}$ & 699.66 & $43,103.72$ & $114,709.3$ & 0.0004 \\
\hline
\end{tabular}


The results of the ecological effect calculation for variant 1 show the highest value for this particle index $\left(E E_{i}=23\right)$ and the lowest for carbon dioxide $\left(E E_{i}=1.08\right)$.

The emission of pollutants into the air from electric buses at their places of use is zero, which justifies the purpose of using these vehicles. The ecological effect of option 2, calculated with regard to emissions during electricity production, is highest for $\mathrm{PM}$ and $\mathrm{NO}_{\mathrm{x}}$ when the energy comes from a natural gas-fired power plant. The highest reductions in $\mathrm{CO}$ emission $\left(E E_{i}=503.33\right)$ and $\mathrm{CO}_{2}$ were achieved in the case of electricity production from biomass. In terms of reducing $\mathrm{CO}_{2}$ emissions, the variant of an electric bus powered from a coal-fired power station is unfavourable. The annual $\mathrm{CO}_{2}$ emissions in the above-mentioned variant are $28 \%$ higher than in the base variant.

Taking into account the pollutant emissions from electricity production, the best cost-effective solution is to use an electric bus powered by a natural gas-fired power plant. For this variant, the unit cost of achieving the environmental effect $\left(K_{j}\right)$ for the pollutants analyzed is lower than for the internal combustion engine. When the emissions in the power generation process are taken into account, a bus with a standard engine has a lower (better) $K_{j}$ cost for $\mathrm{NO}_{\mathrm{x}}, \mathrm{PM}$ and $\mathrm{CO}_{2}$, compared to an electric bus powered from a coal-fired power plant.

\section{REFERENCES}

1. Blue Book (Niebieska Księga). Public transport sector in cities, agglomerations, regions. Joint Assistance to Suport Project and European Regions. New edition, August 2015.

2. Catalog. Solaris Bus \$ Coach S.A. BolechowoOsiedle 2016.
3. Commission Regulation (EU) No 133/2014 of 31 January 2014 amending, for the purposes of adapting to technical progress with respect to emission limit values, Directive 2007/46/EC of the European Parliament and of the Council, EC and Council Regulation No 595/2009 and Commission Regulation (EU) No 582/2011 (OJ L47/1, 18.2.2014).

4. Directive 2005/55/EC of the European Parliament and of the Council of 28 September 2005 on the approximation of the laws of the Member States relating to measures to be taken against gaseous and solid pollutants by vehicles and gaseous pollutants from spark-ignition engines powered by natural gas or LPG used in vehicles (OJ 2006 No 205 item 1512).

5. Kubik B., 2014. Cost evaluation of electric vehicle-based communication. Conference materials: Needs and standards of public services in seven municipalities of the province Lubuskie. Nowy Kisielin, May 28

6. Marczak H., 2016. Energy consumption costs and emissions of pollutant resulting from the use of urban buses. Autobusy, 6, 281-285.

7. MPK in Cracow, Electric buses. Purchase and operating costs. In: E-Bus Conference MaterialsPractical Aspects of Electrification of Public Transport. Warsaw March 30, 2017.

8. Notice of the Minister of the Environment of 29.06.2016 on the amount of fees for using the environment for 2017 (M.P. 2016, item718).

9. PGE GiEK data - The Structure of fuel consumption and emissions in 2016 (online), www.pgegiek. pl/index.php/structure-fuel-fuel/ (08.05.2017).

10. Report Agence de l'Environnement et de la Maitrise de l'Energie, Panorama et evaluation des differentes filieres d'autobus urbains, August 2015.

11. Regulation of the Prime Minister of 10 May 2011 on non-obligatory evaluation criteria for tenders for certain types of public procurement (Journal of Laws of 2011, No. 96 item 559). 